\title{
SEDIMENT CONTAMINANT AND TOXICITY IN KELABAT BAY, BANGKA BELITUNG PROVINCE
}

\author{
Dwi Hindarti*, Zainal Arifin, Rachma Puspitasari, and Endang Rochyatun \\ Research Centre for Oceanography - Indonesian Institute of Sciences, \\ Jl. Pasir Putih 1, Ancol Timur, Jakarta 14430, Indonesia \\ *e-mail: dwihindarti@yahoo.com
}

\begin{abstract}
Sediment of 16 sites in the Kelabat Bay were monitored for metal contamination and toxicity in 2006 . Two patterns of metal contaminants distribution in the sediment were observed. Higher concentrations of lead and copper were found in March than those in July, and so was in the inner bay than those observed in the outer bay, while different pattern was observed for cadmium concentration. The highest lead concentrations were observed at site 7 (inner bay) both in March and July. Although elevated levels of cadmium, lead and copper were observed in sediments, they were still in the tolerable level for marine life. Sediment of the bay was also evaluated for its toxicity using marine phytoplankton, Chaetoceros gracilis and sea urchin, Tripneustes gratila. Results of the tests reveal that no toxic effects of sediment to the growth of phytoplankton were observed, but to sea urchin fertilization of the sediment may have toxic effect.
\end{abstract}

Keywords: Heavy metals, Sediment, Toxicity, Tripneustes gratila, Kelabat Bay.

\section{INTRODUCTION}

The Kelabat Bay of the Bangka Belitung Province is a semi enclosed waters opposite the South China Sea. The bay is a dynamic environment that has highly variable bottom sediment types, diverse biological habitats, and localized deposition. Many activities such as fishing, recreation, shipping, housing, waste disposal and resource preservation are thought to influence the bay. In many cases of the polluted sediments, the ecosystem has suffered detrimental effects (eg. Gagne et al., 2006). Illegal minings have been going on in the adjacent area of the bay for many years and directly discharge the waste into the bay. These activities may be a potential source of metals in the bay. Measures of biological nature were needed to provide a perspective on the toxic chemical contamination occurring in the bay. The chemical data could provide evidence that portions of the estuary are contaminated, but they alone do not demonstrate that the chemicals may be of a significant problem to the biota of the bay.

Sediment plays a major role in an aquatic system since it provides a habitat for many organisms. Contaminants are normally accumulated in sediments and preserved there for a long period, leading to the condition that may affect sedimentary living-organisms. Sediment toxicity test has been widely used to evaluate sediment quality in temperate regions (Chapman and Morgan, 1983; Chapman and Fink, 1984; Mearns et al., 1986; Chapman, et al., 1987; Carr et al., 1996; Thompson et al., 1999). The algal growth test and sea urchin bioassay have been widely used as a rapid and reliable indicator of environmental quality (Roseth et al., 1996; Hindarti et al., 1999; Franklin et al., 2002; Anderson et al., 2001). This sediment bioassay can also be used to characterize the toxicity of marine sediment (PSEP, 1995).

Local government recently assigns the bay as an integrated marine fisheries development area in the future. Information on marine and sediment qualities of the bay are of important for the government to decide whether or not the bay is appropriate for this purpose. The assessments of Kelabat Bay marine environment have been limited on nutrient hydrodynamic (RCO, 2006) and biological resources (RCO, 2004). Because of 
these reason, research was conducted in March and July 2006 to assess the marine environment quality of Kelabat Bay in terms of metals levels in sediment and biota living in the receiving waters. Sediment of Kelabat Bay was also assessed using marine phytoplankton (Chaetoceros gracilis) and sea urchin (Tripneustes gratila) for its toxicity. Phytoplankton was selected as a test organism because the plankton is a primary producer in the aquatic environment. Sea urchin was also used in the test as it is ecologically important and biologically well documented as well as easy to handle. Therefore, the objective of the present study is to provide information of $\mathrm{Pb}, \mathrm{Cd}$ and $\mathrm{Cu}$ concentrations in the sediment and marine organisms as a part of assessing sedimentary toxicities.

\section{MATERIALS AND METHODS}

\section{Study site}

The Kelabat Bay is a semi-enclosed waters that has been used for many purposes by local community for various activities such as fishing, recreation, marine culture, transportation, and waste repository. The major river input is located in the south of the inner bay. The outer bay is influenced by the water flow from the South China Sea. The sandy bottom is the major habitat of the bay. Mangrove ecosystems are found at the edge of the river mouths, and extended to the western of inner and outer of the bay.

Sampling of sediment was conducted during March and July 2006 at 16 sites divided into two simple blocks of the Kelabat Bay, i.e., seven sites in the inner bay (Sites 1, 2, 3, 7, 10, 13, and 16), and nine sites in the outer bay (Sites 4, 6, 9, 11, 12, 14, 15, 17, and 18), (Fig. 1).

Sediments samples were collected using a modified $0.5 \mathrm{~m}$ Smith Mc-InTyre grab. All equipment was rinsed with acetone and site seawater before use at each site to prevent crosscontamination. The top $5 \mathrm{~cm}$ of the sediment was removed from the sampler with a scoop from each of the three replicate grabs, and subsequently homogenized to provide a composite sample. Aliquot samples were taken for both analytical laboratory and sediment bioassays. Water quality parameters including $\mathrm{pH}$, salinity, dissolved oxygen, and temperature were measured in situ.

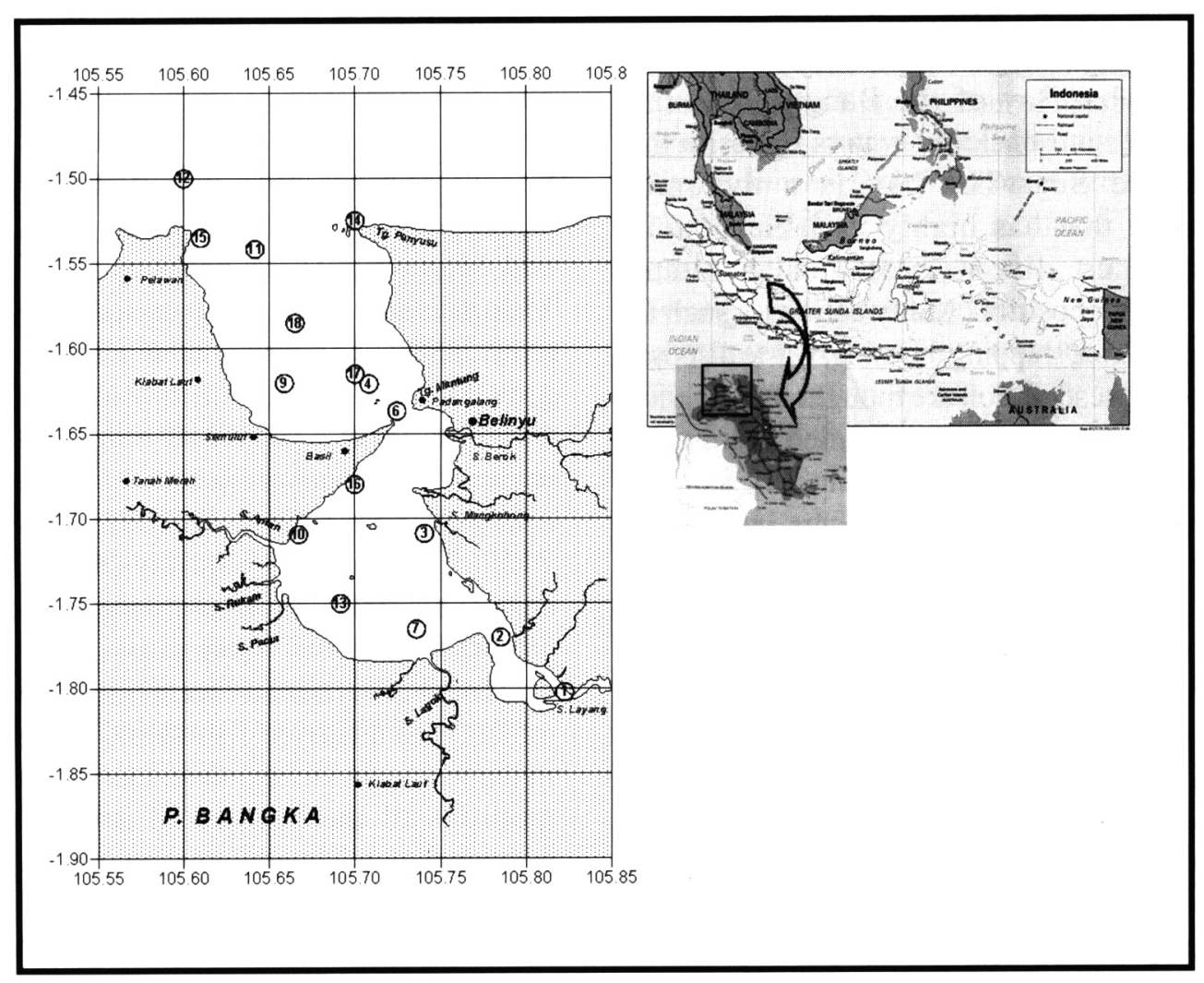

Figure 1. Sampling sites in the Kelabat Bay waters. 


\section{Sediment chemistry}

Metals in sediment were extracted with aqua regia to avoid decomposition of silicate matrix of sediment and to recover the tightly-bound metal fraction (Flegal et al., 1981). Total digestions were performed on the sediment samples. The samples were, then, analyzed for, cadmium, copper, and lead by Spectra AA 10/20 Varian flame atomic absorption spectrometry (FAAS).

\section{Sediment bioassays}

The sediment bioassay using sea urchin was performed only in March sampling. No sediment bioassay was conducted in July sampling due to the non-availability of the gravid animal. In contrast the assay for diatom growth were conducted in both March and July sampling.

The larval of sea urchin (Tripneustes gratila) and algal (Chaetoceros gracilis) growth bioassays were conducted using sediment elutriate (water soluble fraction) with percent larval development after $48 \mathrm{~h}$ (Environment Canada, 1992) and number of cells after $96 \mathrm{~h}$ (ASTM, 1992) as end points.

The algae were cultured in sterile modified Walne s medium. The medium is not chelator free (with EDTA) and was sterilized by standard autoclaving procedure. An initial stock culture was adjusted to $1 \times 10^{6}$ cells ml ${ }^{-1}$. The elutriate test used in monitoring programs was to provide information about elutriate toxicity at site in the bay. Elutriates solutions were prepared by adding eighteen grams of test sediment and $900 \mathrm{ml}$ of filtered and UV-treated seawater, vigorous shaking for 10 minutes, settling for $4 \mathrm{~h}$ and carefully decanting the aluate (PSEP, 1995). These solutions were also used for the algal growth test. Reference toxicant (positive control) test with cadmium chloride was run for each series of tests to assess the viability of the test organisms.

\section{Bioaccumulation}

Samples of fishes and mollusks from the Kelabat Bay during March and July were obtained from the fisherman. The number of samples and species depended on seasonal availability. Two species of mollusk (Cerithidea cingulata and Anadara granosa) and one species of fish (Nemimterus sp) were collected in March. Seven species of fishes (Caesio cuning, Arius thalasinus, Siganus canaliculatus, Psettodes erumei, Cynoglassus spp, Nemimterus spp., and
Lutjanus fulviflama) and three species of mollusk (Cerithidea cingulata, Anadara granosa and Strombus canarium) were collected in July. Each species of mollusk collected were grouped into size classes based on shell length. Individual species of each size were composed to provide a sufficient sample size. All contaminant measured were expressed in a dry weight basis to get an accurate measurement of metal (Cohen et al., 2001).

\section{Data analyses}

For sea urchin larval development data, the trimmed Spearmen-Karber method (Hamilton et al., 1977) with Abbott s correction was used to calculate effective concentration (EC50) values for dilution series test of reference toxicant. Analysis of variance (ANOVA) was used to differentiate between test and control samples. Dunnetts multiple comparison test was performed to determine significant differences of each site from the control. The relationships between measures of contamination and measures of toxicity were determined using t-test.

\section{RESULTS}

\section{Distribution of contaminants in sediment and biota}

The chemical analyses showed that two patterns of contaminants distribution were observed. In general, higher concentrations of metals were found in March than those observed in July, and so were in the inner bay than those observed in the outer bay with the exception of cadmium (Fig. 2, 3, 4). Concentrations of lead were generally higher in the inner bay than those found in the outer bay during March and July sampling period. High concentrations of lead were obtained from March samples collection (Fig. 2).

Concentration of cadmium at low level ranged from 0.01 to $0.7 \pm \mathrm{g} \mathrm{g}^{-1}$ dry weight was generally found in all sites during March and July. Moreover, its undetected concentration had been shown in sites $7,10,12,13,16$, and 18 (Fig. 3). The highest cadmium concentration exceeding $0.7 \pm \mathrm{gg}^{-1}$ dry weight was found in site 16 in March. Higher copper concentrations were found significantly in the inner bay in March than those observed in the outer bay in July (Fig. 4). 


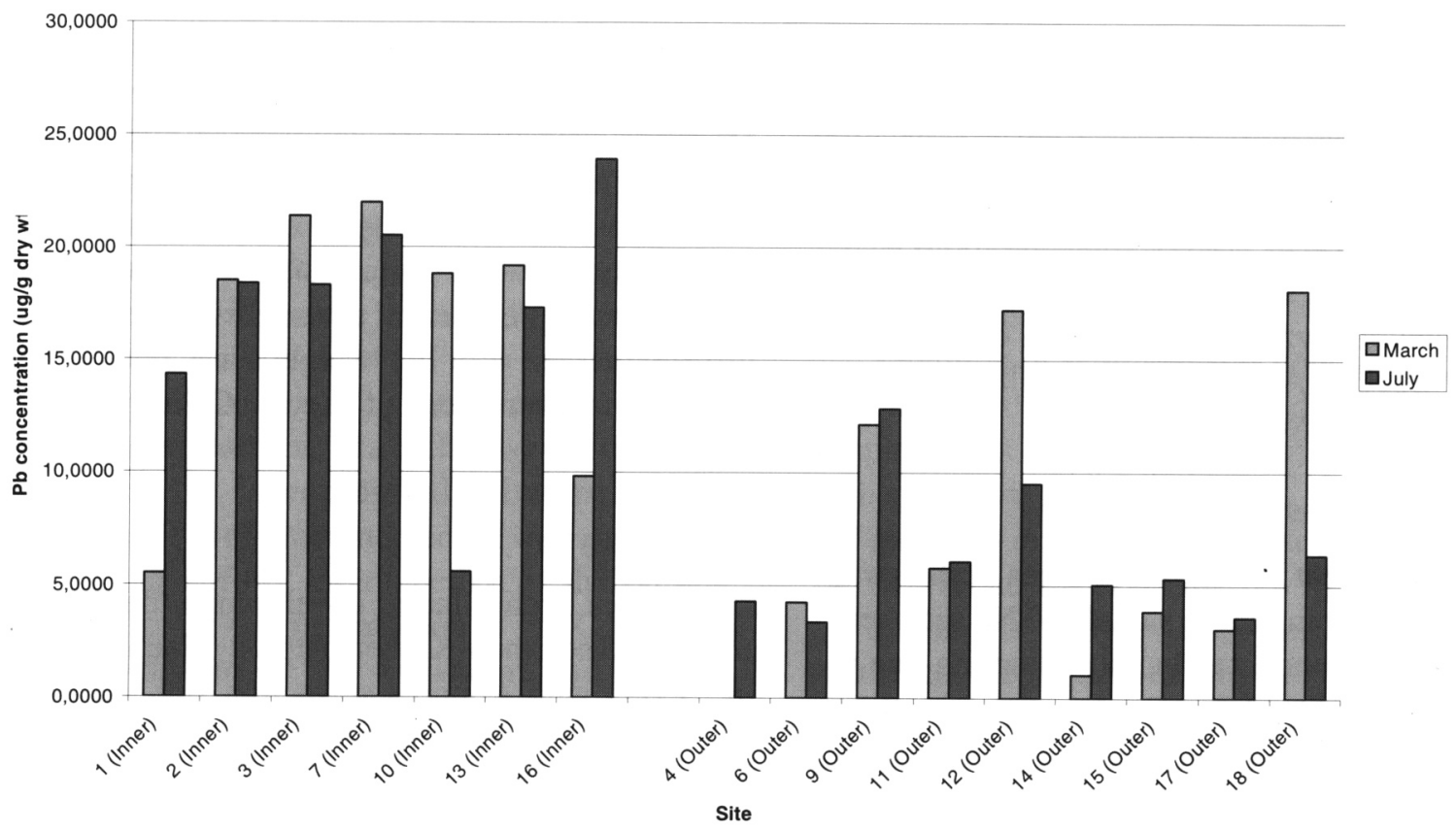

Figure 2. Pb concentrations ( $\pm \mathrm{g} \mathrm{g}^{-1}$ dry wt) observed in sediment of Kelabat Bay in March and July 2006.

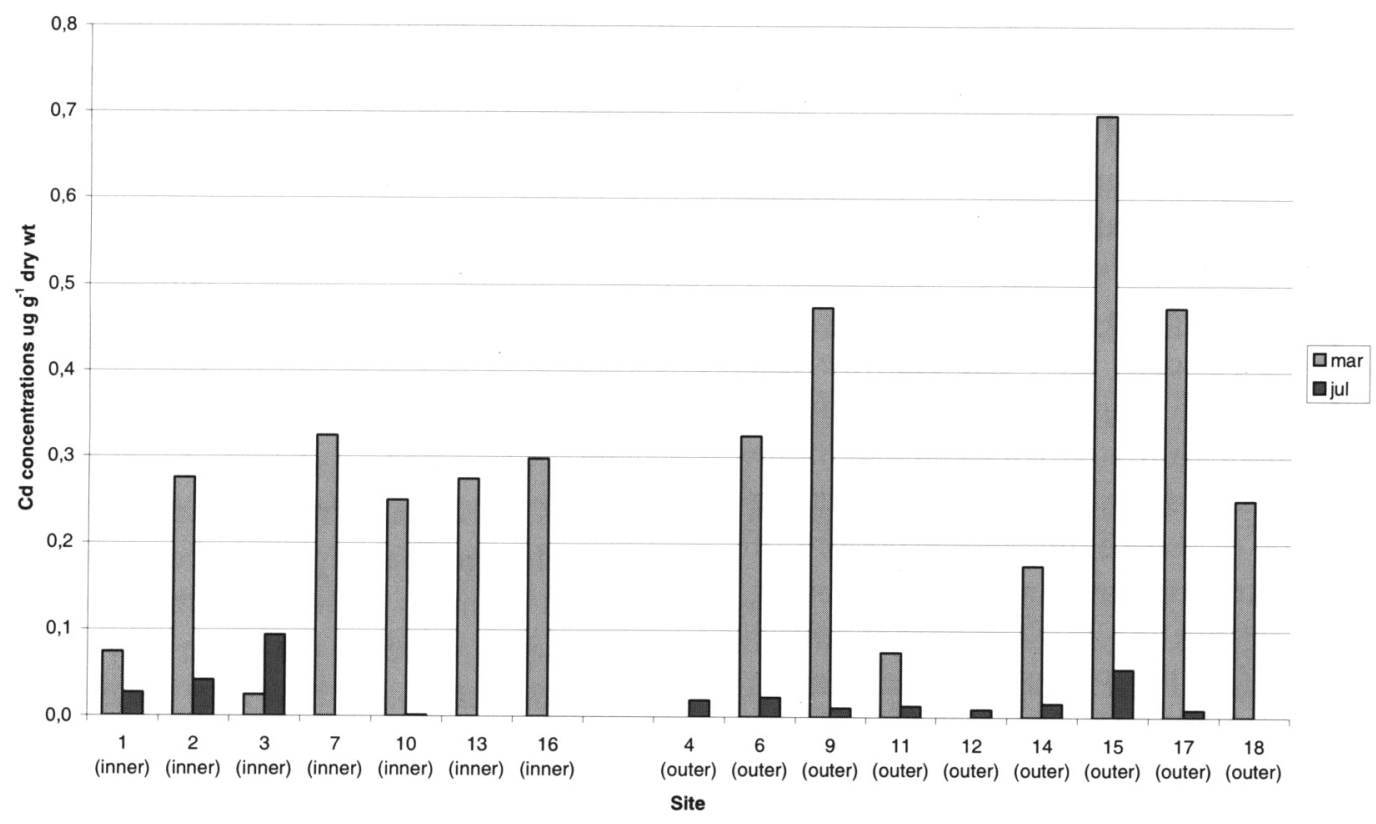

Figure 3. Cd concentrations ( $\pm \mathrm{g} \mathrm{g}^{-1}$ dry wt) observed in sediment of Kelabat Bay in March and July 2006.

\section{Sediment bioassays}

The parameters of water quality measured during the test were within acceptable limits. Most of the sediments tested (14 sites) were apparently toxic to sea urchin larval development except for the site 13 and 15 (Fig. 5). The test endpoint was indicated by the abnormality. These tests were considered valid since the mean of abnormality in the seawater control was $8.0 \%$. Mortality of the larvae was less than $10 \%$ in all of the tested sediments. These tests were also considered valid since the mean of abnormality in the controls was below the maximum of $10 \%$ criterion for seawater set by Environment Canada (1992). Abnormality in the tested sediment ranged from $10.47 \%$ to $59.57 \%$. Both of the lowest (site 13) and the highest (site 10) abnormality values were located in the inner bay. The average value of abnormality larvae in the inner bay was slightly lower than those of in the outer bay. The $\mathrm{EC}_{50}$ value for the cadmium positive control test was $2.613 \mathrm{mg} \mathrm{l}^{-1}$. 


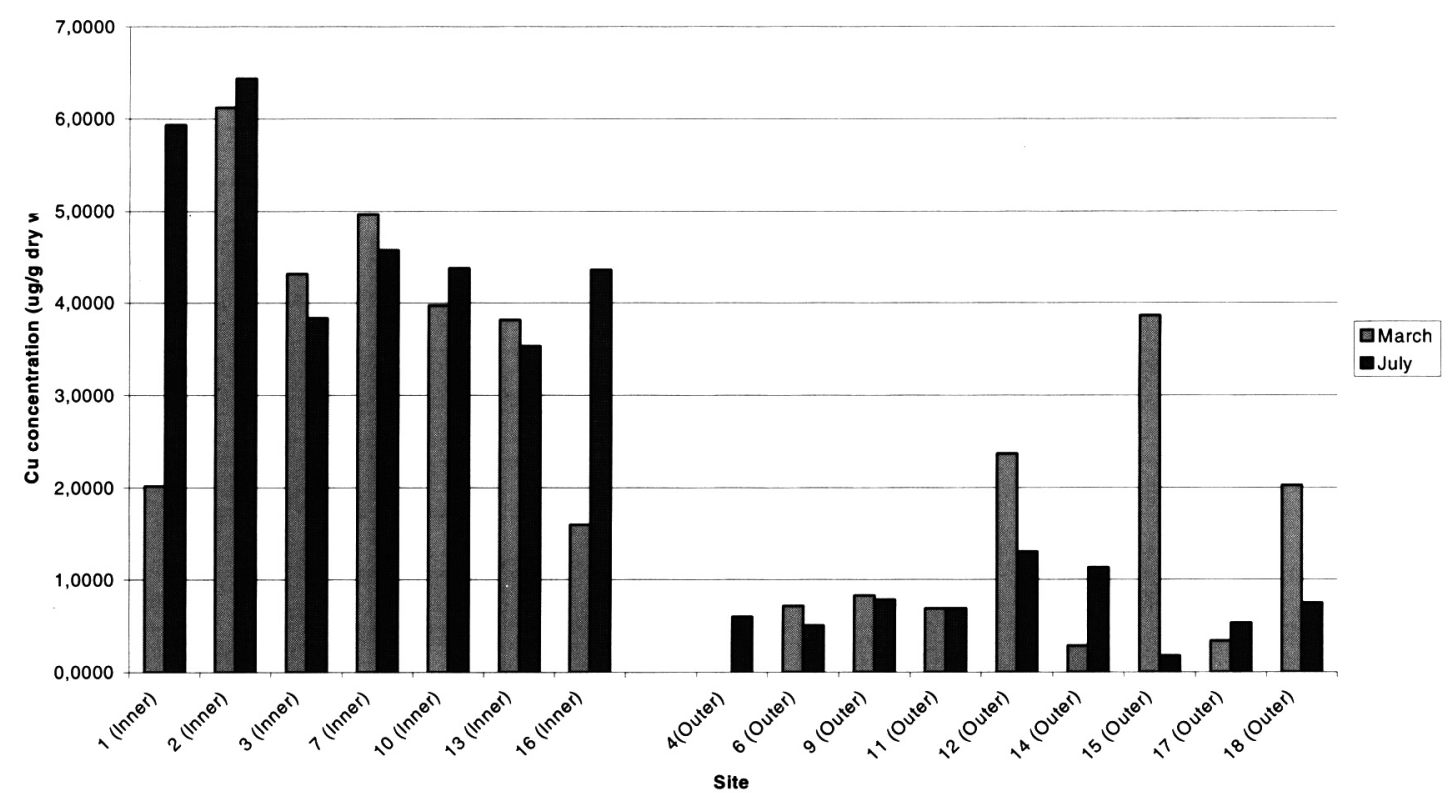

Figure 4. $\mathrm{Cu}$ concentrations $\left( \pm \mathrm{g} \mathrm{g}^{-1} \mathrm{dry}\right.$ wt) observed in sediment of Kelabat Bay in March and July 2006.

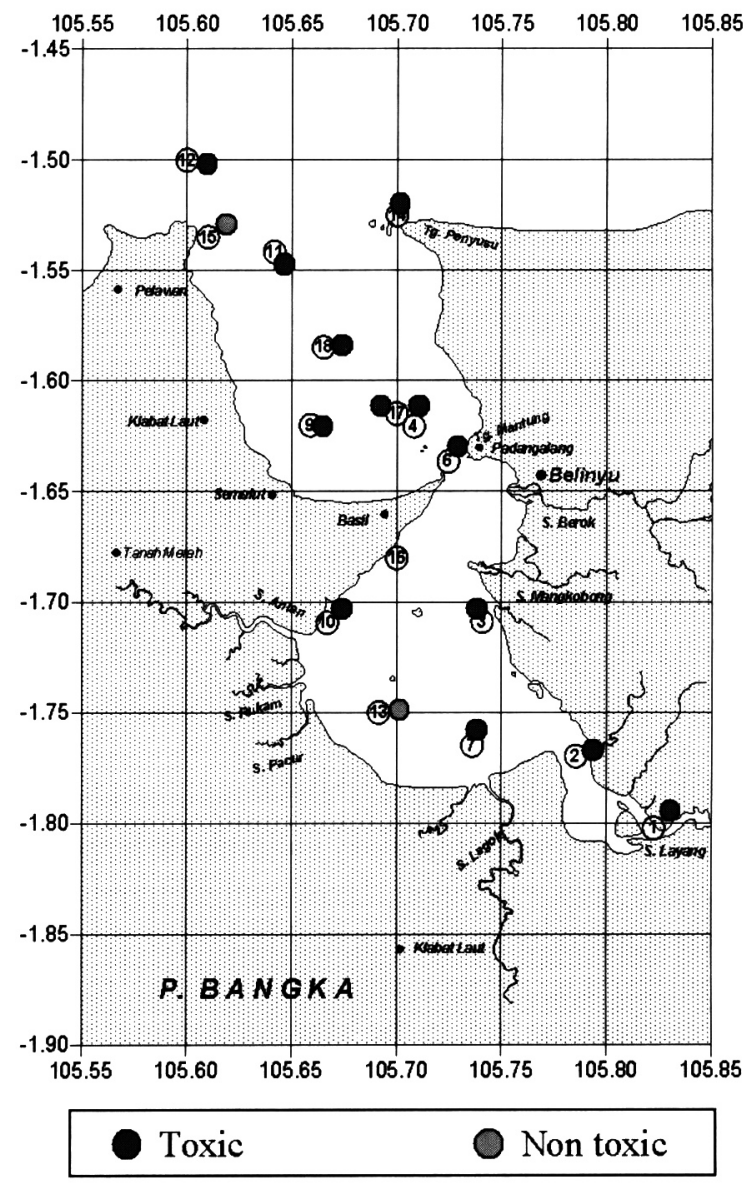

Figure 5. Toxicity of sediment elutriate to sea urchin larval development bioassay for sites of March 2006.
Growth of algae was expressed as cell number in each treatment. Results of sediment elutriate toxicity test using marine diatom are provided in Figure 6. Growth of diatom (cells $\mathrm{ml}^{-1}$ ) was generally lower in July than that in March. The $\mathrm{IC}_{50}$ values of the cadmium control positive in March and July were $1.82 \mathrm{mg} \mathrm{l}^{-1} \mathrm{Cd}$ and $1.48 \mathrm{mg}$ $\mathrm{l}^{-1} \mathrm{Cd}$, respectively. These values were within the laboratory range of $1.80 \pm 0.94 \mathrm{mg} \mathrm{l}^{-1} \mathrm{Cd}$.

In order to compare the effects of sediment in the bay on the growth of algae, test sediments were divided into two groups, the inner bay (sites 1,2,3, $7,10,13$, and 16) and the outer bay (sites 4, 6, 9, 11, 12, 14, 15, 17, and 18), (Fig. 1). Results of the analysis of variance indicated significant differences within algae cell density among sites. In March bioassay, the cell density of $C$. gracilis in most of the test sediment elutriate of inner bay was significantly higher than those found in the control seawater $(p<0.05)$. No significant difference in the growth of algae exposed to the outer bay sediment elutriate was observed during March sampling. Similarly, no significant difference in the growth of algae was also found from July sampling period both in the inner and outer bay. But the cell densities of $C$. gracilis in the test sediment of March were significantly higher than those of July $(\mathrm{p}<0.05)$. 




Figure 6. Effect of sediment on marine phytoplankton growth.

\section{Bioaccumulation of metals}

Generally, $\mathrm{Pb}, \mathrm{Cd}$ and $\mathrm{Cu}$ concentrations in all species in March were found higher than those observed in July (Table 1). Copper exhibited high concentration in all species collected in March. Concentration of $\mathrm{Pb}$ was higher than that of $\mathrm{Cd}$ and $\mathrm{Cu}$ in all species collected in July. Cadmium and copper were generally present in low concentration in fishes, and high concentration in mollusks except in the milk conch (Strombus canarium). The metals concentration in different species collected from the Kelabat Bay generally varied as follows: $\mathrm{Cu}>\mathrm{Pb}>\mathrm{Cd}$ in March and $\mathrm{Pb}>\mathrm{Cu}>\mathrm{Cd}$ in July.

\section{DISCUSSION}

\section{Patterns in sediment contamination}

Generally, metals contaminants $(\mathrm{Pb}, \mathrm{Cd}$ and $\mathrm{Cu}$ ) in sediment found to be higher in the inner bay than those observed in the outer bay. This suggests that contaminants in the sediment were influenced by land-based activities and biophysical processes (tides and bioresuspension). Tidal current has been reported to influence the transport of sediment particles in the estuarine system (Kitheka et al., 2005). Patchy distributions of contaminants in sediments are associated with both source proximity and natural variations in sediment deposition and transport processes. The degree of uncertainty due to spatial variability must be considered in all environmental assessments (Brink et al., 1997).

However, most of the metal concentrations in sediment did not exceed the Probable Effect Level (PEL) set by the Canadian Environmental Quality Guidelines (CCME, 2002), the only metal exceeded the PEL $\left(0.07 \pm \mathrm{g} \mathrm{g}^{-1}\right)$ was cadmium at site 16 (outer bay). It is necessary to understand the mobility, transport rates, paths, and sinks of sedimentary particles and associated contaminants for predicting both the fate of substances that have been introduced into the environment and any risk associated with their presence (Brink et al., 1997).

\section{Patterns in sediment toxicity}

The results of this study indicated that the two toxicity tests exhibited significant differences in their sensitivities. The sea urchin fertilization test was more sensitive than that of the marine phytoplankton test. In the March sampling, 87.5\% of the sites were toxic in the sea urchin fertilization test. This study is in agreement with previous study done by Anderson et al. (2001). They stated that the sediment pore water exposures inhibits strongly the sea urchin (Strongylocentrotus purpuratus) embryo development than that of the sediment-water interface. In contrast to the negative effect on larval development of sea urchin, 
Table 1. $\mathrm{Pb}, \mathrm{Cd}$ and $\mathrm{Cu}$ concentrations in selected species in Kelabat Bay (average; $\pm \mathrm{g} \mathrm{g}^{-1}$ dry weight).

\begin{tabular}{|l|c|c|c|c|c|}
\hline Species & Sampling Period & $\mathbf{N}$ & $\mathbf{P b}$ & $\mathbf{C d}$ & $\mathbf{C u}$ \\
\hline Fishes & & & & & \\
\hline Nemimterus spp. & March & & 3.9 & 0.5 & 1.4 \\
\hline Caesio cuning & July & & 5.9 & 0.5 & 0.3 \\
\hline Arius thalasinus & July & & 4.6 & 0.4 & 0.4 \\
\hline Siganus canaliculatus & July & & 7.1 & 0.5 & 0.5 \\
\hline Psettodes erumei & July & & 5.1 & 0.3 & 0.7 \\
\hline Cygnoglassus spp & July & & 4.1 & 0.3 & 0.5 \\
\hline Nemimterus spp & July & & 5.6 & 0.3 & 0.6 \\
\hline Lutjanus vulviflama & July & & 6.3 & 0.5 & 0.4 \\
\hline & & & & & \\
\hline Mollusks & & & & & \\
\hline Cerithidea cingulata & March & & 13.6 & 2.4 & 19.6 \\
\hline Cerithidea cingulata & July & 28 & 13.8 & 1.0 & 4.4 \\
\hline & & 30 & 13.1 & 1.1 & 4.4 \\
\hline Anadara granosa $(2.0-2.5 \mathrm{~cm})$ & March & & 8.8 & 6.1 & 3.9 \\
\hline Anadara granosa (3.0-3.5 cm) & March & & 8.0 & 7.3 & 16.3 \\
\hline Anadara granosa & July & 7 & 7.6 & 4.5 & 3.4 \\
\hline & & 8 & 6.6 & 4.2 & 3.5 \\
\hline & & 10 & 6.2 & 5.1 & 3.2 \\
\hline Strombus canarium & July & 5 & 9.1 & 0.6 & 7.9 \\
\hline & & 4 & 9.7 & 0.5 & 6.2 \\
\hline & & 4 & 9.0 & 0.6 & 6.1 \\
\hline
\end{tabular}

the sediment toxicity did not influence the growth of algal. One of the explanations of no toxicity effect of sediment exposure on algal growth is that the sediment may have high nutrients content. Hence, the availability of nutrients reduce metal toxicity during algal growth period.

\section{Correlation between metals in sediment and sediment toxicity}

The causes of toxicity in the Kelabat Bay sediments apparently could not be identified with the data collected. Toxicity identification evaluations
(TIEs) under controlled laboratory conditions are required to determine those relationships (Carr et al., 1996). The most associated chemicals with toxicity were identified with correlation analyses. Spearman rank correlation coefficients were determined to identify patterns in covariance between the concentrations of potential toxicants and the measures of toxicity. Table 2 summarizes the Spearman rank correlation coefficients for toxicity and metals data and shows that data of the marine diatom growth within March and July have been averaged to determine the correlation

Table 2. Spearman rank correlation coefficients (negative sign indicates an inverse correlation) between toxicity data and concentrations of metals in sediment.

\begin{tabular}{|l|c|c|}
\hline Sediment contaminant & Marine diatom growth & Sea urchin fertilization \\
\hline Cadmium & -0.275 & -0.172 \\
\hline Lead & -0.035 & -0.113 \\
\hline Copper & 0.014 & -0.172 \\
\hline
\end{tabular}


coefficients for the effect of metals on the growth of marine diatom. However, statistically, no matching potential toxicant concentrations in sediment and toxicity data were produced in all samples. Despite the fact that exposure of chronic level of cadmium had produced an adverse effects on gamete quality (Au et al., 2001). Thomson et al. (1984) showed that the bioavailability of metals did not coincide with metal enrichment in sediments. Moreover, the total metal concentration in the sediment do not necessarily correlated to the bioavailability to the biota. Generally, only dissolved fraction of lipophilic contaminants are considered to be bioavailable to aquatic organisms (Kaag et al., 1997)

In addition, those results are difficult to interpret because they relate concentrations measured in bulk sediments with the results of bioassays using sediment elutriates. Since elutriate chemistry was not measured, it was not possible to evaluate the relationship between sea urchin and marine diatom toxicity and elutriates concentrations. A work of Thompson et al., (1999) reported that ratio elutriates and bulk sediment concentrations were very low and inconsistent. Therefore, this relationship between bioassays and elutriates concentrations presumed to be evaluated by means of an appropriate analysis. The assessment of sediment quality generally involves an evaluation of solid-phase sediment, together with the pore water, because it can represent its major route of exposure of benthic organisms (Carr et al., 1996).

\section{Bioaccumulation phenomenon}

The results of this study showed that each species demonstrate a different way to regulate contaminants in their body. Mollusks accumulated higher concentration of metals than those observed in fish which are pelagic fish species. Bioaccumulation of trace metals by aquatic organisms were reported varies with species and specific condition (Ruus et al., 2005), also bioaccumulation of compounds will depend on its characteristics. This study was also in agreement with a similar study conducted by Cohen $e t$ al. (2001) that bivalve accumulated higher trace metals than those observed in both bottom-dwelling fish and water column fishes. When clams are used as an indicator of metal enrichment, comparison of concentrations between sites may be affected by the size of organisms collected.
This study revealed high concentration of metals were present in larger size of bivalve mollusk. Strong correlation between metal concentration and size was also reported in previous study for the blue mussel, M. edulis (Boalch et al., 1981), season and size in the common cockle (Cerastoderma edule (L.) (Savari et al., 1991), size and season in Diastylis rathkei (köyer) (Swaileh and Adelung, 1995).

Measures of metals indicated high level of lead in the sediment of Kelabat Bay in all sampling period. Organisms exposed to high level of lead may affect the shell composition (Almeida et al., 1998). The physiological and ecological characteristics of organisms were also reported as factors affecting the availability of trace metals to organisms (Jenne and Louma, 1977 in Ruus et al., 2005). The mechanisms of bioavailability are influenced by the physiological, biochemical, geochemical and ecological controls on the process (Louma, 1983). Hence, an integrated systems approach that includes geochemistry, geology, oceanography, and biology is necessary to develop predictive capabilities for contaminant fate and transport in coastal environments (Brink et al., 1997).

\section{CONCLUSION}

Measurement of sediment chemistry and sediment bioassays conducted in the Kelabat Bay in 2006 indicated that generally enrichment in sediment has occurred. The two sediments elutriate bioassays demonstrated clearly the different patterns of toxicity. Differences of sensitivities of the species, life stages and endpoints all might be contributing to those differing patterns. Both sea urchin and marine phytoplankton tests provide information on the effects of contaminants in the water soluble fraction of sediment on sea urchin sperm viability and growth of marine phytoplankton.

No strong correlation between sediment contamination and toxicity at all of the Kelabat Bay sites was probably due to the comparison was made for sediment contamination values that calculated from measurements of contaminant in bulk sediment, while sea urchin and marine diatom bioassays was performed from sediment elutriates. 
Acknowledgement. This study was funded by the Indonesian Government through the Research Project on Marine Science and Technology of the Research Centre for Oceanography, Indonesian Institute of Sciences. The authors would like to thank Mrs. Woro Widiarsih and Dr. Tri Prartono for their constructive suggestions. Great appreciation to Rahmawati Febriana, Eston Matondang, Triyoni Purbonegoro, Abdul Rozak and Taufik Kaisupi for their technical assistance and also to many others that can not be mentioned all for their support.

\section{REFERENCES}

Almeida, M.J., G. Moura, T. Pinheiro, J. Machado, and J. Coimbra. 1998. Modifications in Crassosstrea gigas shell composition exposed to high concentrations of lead. Aquat. Toxicol., 40: 323-334.

Anderson, B.S., J.W. Hunt, B.M. Phillips, R. Fairey, H.M. Puckett, M. Stephenson, K. Taberski, J. Newman, and R.S. Tjeederma 2001. Influence of sample manipulation on cantamination flux and toxicity at the sediment-water interface. Mar. Environ. Res., 51: $191 \longleftarrow 211$.

ASTM, 1992. Guide for conducting static 96-h toxicity tests with microalgae. E 1218 90. In: Annual book of ASTM standards, water and environmental technology, vol. 11.04. American Society for Testing Materials, Philadelphia, Pennsylvania, p. 874 882 .

Au, D.W.T., C.Y. Lee, K.L. Chan, and R.S.S. Wu. 2001. Reproductive impairment of sea urchins upon chronic exposure to cadmium. Part I: Effects on gamete quality. Environ. Pollut., 111: 1`9.

Boalch, R., S. Chan, and D. Taylor. 1981. Seasonal variation in the trace metal content of Mytilus edulis. Mar. Pollut. Bull., 12(8): 276 280.

Brink, M.B., M.H. Bothner, F.T. Manheim, and B. Butman. 1997. Contaminant metals in coastal marine sediments a legacy for the future and a tracer of modern sediment dynamics. Proceedings of the U.S. Geological Survey (USGS) Sediment Workshop, February 477, 1997.

Carr, R.S., E.R. Long, H.L. Windon, D.C. Chapman, G.Thursby, G.M. Sloane, and W.A. Wolf. 1996. Sediment quality assessment studies of Tampa Bay, Florida. Environ., Toxicol., Chem., 15(7): $1218 \smile 1231$

CCME (Canadian Council of Ministers of the Environment). 2002. Summary of existing Canadian Environmental Quality Guideline. 12pp.
Chapman, P.M., and J.D. Morgan. 1983. Sediment bioassays with oyster larvae. Bull. Environ. Contam. Toxicol., 31: 438444.

Chapman, P.M., and R. Fink. 1984. Effects of Puget Sound sediments and their elutriates on the life cycle of Capitella capitata. Bull. Environ. Contam. Toxicol., 33: 451`459.

Chapman, P.M., R.N. Dexter, and E.R. Long. 1987. Synoptic measures of sediment contamination, toxicity and infaunal community composition (the Sediment Quality Triad) in San Fransisco Bay. Mar. Ecol. Prog. Ser., 37: 75`96.

Cohen, T., S.Q.E. Shane, and F.A. Richard. 2001. Trace metals in fish and invertebrate of the California Coastal Wetlands. Mar. Pollut. Bull., 42(3): 224 232.

Environment Canada. 1992. Biological Test Methods: Fertilization Assay using Echinoids (sea urchins and sand dollars). Environmental Protection Series. Report EPS 1/RM/27.97pp.

Flegal, A.L., L.S. Cuter, and J.H. Martin. 1981. A study of chemistry of marine sediments and wastewater sludge. Sacramento: CA. California State Water Research Control Board.

Franklin, N.M., L. Sauber, S.C. Apte, and R.P. Lim 2002. Effects of initial density on the bioavailability and toxicity of copper in microalgal bioassays. Environ. Chem. Toxicol., 21(4): 742 751.

Gagne, F., C. Blaise, J. Pellerin, E. Pelletier, and J. Strand. 2006. Health status of Mya arenaria bivalves collected from contaminated sites in Canada (Saqueay Fjord) and Denmark (Odense Fjord) during their reproductive period. Ecotox. Environ. Health, 64: $348 \smile 361$

Hamilton, M.A., R.C. Russo, and R.V. Thurston. 1977. Trimmed Spearman-Karber method for estimating median lethal concentration in toxicity bioassays. Environ. Sci. Technol., 11: 714719; correction 1978, 12:417.

Hindarti, D., Y. Darmayati, Sulistijo and M.G.L. Panggabean. 1999. Effects of Jakarta Bay Sediments on Green Mussel (Perna viridis) and Phytoplankton (Chaetoceros gracilis and $C$. ceratosporum). In: I. Watson, Vigers, G.A., K.S. Ong, C. McPherson, N. Millson, A. Tang, and D. Gass (Eds.). ASEAN Marine Environmental Management: Towards Sustainable Development and Integrated Management of the Marine Environment in ASEAN. Proceeding of the ASEANCanada Technical Conference on Marine Science (26-30 October), Langkawi, Malaysia. EVS Environments Consultants, North Vancouver and Department of Fisheries Malaysia. 609pp. 
Kaag, N.H.B.M, E.M., Foekema, M.C.Th. Scholten, and N.M. van Straalen. 1997. Comparison of contaminant accumulation in three species marine invertabrates with different feeding habits. Environ. Tox. Chem., 16(5): 837-842.

Kitheka, J.U., M. Obiero, and O. Nthenge. 2005. River discharge, sediment transport and exchange in the Tana Estuary, Kenya. Estuarine, Coastal and Shelf Science, 63: 455-468.

Louma, S.N. 1983. Bioavailability of trace metals to aquatic organisms “ a review. Sci. Tot. Environ., 28: $1-22$

Mearns, A.J., R.C. Swartz, J.M. Cummins, P.A. Dinnel, P. Plesha, and P.M. Chapman. 1986. Inter-laboratory comparison of a sediment toxicity test using the marine amphipod, Rhepoxynius abronius. Mar. Environ. Res., 19: 13-37.

PSEP (Puget Sound Estuary Program). 1995. Recommended guidelines for conducting laboratory bioassays on Puget Sound Sediment. U.S. Environmental Protection Agency Authority. Puget Sound Water Quality. Seattle. US. 96pp

RCO. 2004. Fish resources potential and the environment for supporting integrated fisheries industry in Kelabat Bay and Belitung waters, Bangka Belitung Islands Province. Research Centre for Oceanography (RCO), Indonesian Institute of Science. 26pp.

RCO. 2006. Research on river stream system hydrology, hydrodynamic and material budget of Kelabat Bay, Bangka Belitung. Annual Report. Research Centre for Oceanography (RCO), Indonesian Institute of Sciences. 61pp. (in Indonesia)

Roseth, S., T. Edvardsson, T.M. Botten, J. Fuglestad, F. Fonnum, and J. Stenerse. 1996. Comparison o acute process chemicals used in the oil refinery industry tested with the diatom Chaetoceros gracilis, the flagellate Isochrysis galbana and the zebra fish Brachydanio rerio. Environ. Chem. Toxicol., 15(7): 1211`1217.

Ruus, A., M. Schaanning, S. Æxnevad, and K. Hylland. 2005. Experimental results on bioaccumulation of metals and organic contaminants from marine sediment. Aquat. Toxicol., 72: 273 292.

Savari, A., A.P.M. Lockwood, and M. Sheader. 1991. Effects of season and size (age) on heavy metal concentrations of the common cockle (Cerastoderma edule (L.) from the Southampton waters. Journal of Molluscan Studies, 57: 45`57.

Swaileh, K.M., and D. Adelung. 1995. Effect of body size and season on the concentration of $\mathrm{Cu}, \mathrm{Cd}$, $\mathrm{Pb}$ and $\mathrm{Zn}$ in Diastylis rathkei (köyer) from Kiel Bay, Western Baltic. Mar. Pollut. Bull. 131(1`3): $103 \smile 107$.

Thomson, E.A., S.N. Louma, C.E. Johansson, and D.J. Cain. 1984. Comparison of sediments and organisms in identifying sources of biologically available trace metal contamination. Wat. Res., 18(5) $775^{\sim} 765$.

Thompson, B., B.A. Anderson, J. Hunt, K Taberski, and B. Phillips. 1999. Relationship between sediment contamination and toxicity in San Fransisco Bay. Mar. Environ. Res., 48: 285`309. 